\title{
Autocrine Stimulation by Erythropoietin and Autonomous Growth of Human Erythroid Leukemic Cells In Vitro
}

\author{
Maria-Teresa Mitjavila, * Jean-Pierre Le Couedic," Nicole Casadevall,` Sébastien Navarro, * \\ Jean-Luc Villeval,* Anne Dubart, * and William Vainchenker* \\ *Institut National de la Santé et de la Recherche Médicale (INSERM) U 91, Hôpital Henri-Mondor, \\ Créteil, 94010 France; and ${ }^{\ddagger}$ INSERM U 152, Hôpital Cochin, Paris, 75014 France
}

\begin{abstract}
Autonomous colony formation is a frequent event in erythroleukemia. In 13 cases of early erythroid leukemias, we investigated whether erythropoietin (Epo) autocrine stimulation was responsible for the growth factor autonomy. Epo transcripts were detected by Northern blotting in cells from one patient. These cells also expressed an Epo receptor (1,000 receptors per cell) with a 420-pM affinity and Epo was detected in the supernatant of cultured cells. In 8 of the 13 cases, Epo transcripts were revealed by the polymerase chain reaction ranging from 0.5 to 500 copies per cell. In situ hybridization proved that these Epo transcripts were present in the blast cells. No Epo gene abnormalities were detected by Southern blotting. In two cases, leukemic cells were grown in the presence of Epo-neutralizing antibodies or Epo antisense oligomers. In one case, the antibody significantly reduced autonomous growth. In contrast, the antibody had no effect in the second case in which blast cells transcribed the Epo gene at a low level. However, Epo antisense oligomers partially inhibited autonomous growth. This inhibition was reversed by addition of exogenous Epo. Overall, these results suggest that an extracellular or intracellular autocrine Epo stimulation occurs in some cases of erythroid malignancies. (J. Clin. Invest. 1991. 88:789-797.) Key words: erythroleukemia • autonomous growth • autocrine stimulation • erythropoietin
\end{abstract}

\section{Introduction}

Human erythroid malignant pathologies are of two types. The first, polycythemia vera, is a chronic disease that associates an erythroid hyperplasia with a normal erythroid differentiation and involves a pluripotent stem cell (1). The second consists of true erythroid leukemias. However, these leukemias are quite heterogenous at the cellular level and arise from blockages at different stages of erythroid differentiation. Erythroleukemia (M6 in the French American British classification) is characterized by marked erythroid hyperplasia with major erythroid morphological defects, together with the presence of circulating erythroblasts and marrow blast cells (2). Recently, we and others (3-7) have identified a new type of erythroleukemia in which leukemic cells are blocked at an early stage of erythroid

Address correspondence to Dr. W. Vainchenker, INSERM U 91, Hôpital Henri Mondor, Créteil 94010, France.

Received for publication 2 November 1990 and in revised form 12 March 1991.

J. Clin. Invest.

(c) The American Society for Clinical Investigation, Inc. 0021-9738/91/09/0789/09 \$2.00

Volume 88, September 1991, 789-797 differentiation and are not morphologically identifiable. In the absence of differentiation markers, these forms are classified as either undifferentiated, lymphoblastic, or even monoblastic leukemias and have been termed cryptic erythroleukemia (4) or early erythroid leukemia (3).

These early erythroid leukemias can be subclassified into two types (3). One corresponds to cells blocked at a stage of differentiation identical to that of CFU-erythroid. The main differentiation markers expressed are carbonic anhydrase 1 (CA1) ${ }^{1}$, cluster of differentiation 36 (CD36), glycophorin C (3), transferrin receptors, and often $\mathrm{A}, \mathrm{B}$, and $\mathrm{H}$ blood groups. In the second, the erythroid leukemic cells correspond to proerythroblasts or pre-proerythroblasts (8), with the presence of glycophorin A (GPA) but rarely of hemoglobin (3). These erythroid leukemic cells have specific ultrastructural characteristics which include the presence of ferritin aggregates and peculiar $\theta$ granules $(7,9)$. While differing in their phenotype, all these erythroid malignancies exhibit some degree of factor-independent growth. In polycythemia vera, spontaneous erythroid colony formation (10-12) may be related either to true erythropoietin (Epo) independence (13) or to Epo hypersensitivity $(14,15)$. We have recently shown that most cases of early erythroid leukemia are also Epo independent, since spontaneous leukemic colony formation occurs in serum-free conditions, even in limiting-dilution experiments (16). However, as in polycythemia vera, Epo increases the plating efficiency of the leukemic cells. Similar results have been described in M6 leukemia (17).

It appears therefore that the bypass of exogenous Epo could be a mechanism involved in human erythroid malignancies. A similar phenomenon has been observed in a murine erythroleukemia. Recent studies have shown that the Friend spleen focus-forming virus induces Epo independence through the specific interaction of glycoprotein 55 (Gp55), a viral envelope protein, with the Epo receptor which may thereby trigger cell growth (18-20).

In this study, we investigated whether autocrine stimulation by Epo could explain the autonomous growth of human erythroid leukemic cells. In the majority of cases, leukemic erythroid cells were found to synthesize Epo mRNA and true autocrine stimulation by Epo was observed in one case.

\section{Methods}

Patients. 13 patients with early erythroid leukemia were studied (Table I). Seven of these subjects have already been studied in detail (patients

1. Abbreviations used in this paper: $\mathrm{CA} 1$, carbonic anhydrase $1 ; \mathrm{CD} 36$, cluster of differentiation 36; Epo, erythropoietin; Gp55, glycoprotein 55; GPA, glycophorin A; PCR, polymerase chain reaction; rh, recombinant human. 


\begin{tabular}{|c|c|c|c|c|c|}
\hline \multirow[b]{3}{*}{ Patients } & \multirow[b]{3}{*}{ Primary disease } & \multicolumn{2}{|c|}{ PCR } & \multirow[b]{3}{*}{ Epo receptors } & \multirow[b]{3}{*}{ Autonomous growth } \\
\hline & & \multicolumn{2}{|c|}{ Epo transcripts } & & \\
\hline & & Primers $5^{\prime}$ & Primers $3^{\prime}$ & & \\
\hline 1 & $\operatorname{Tr} 21$ & 0 & $+1-$ & ND & No growth \\
\hline 2 & De novo & +++ & +++ & ++ & ++ \\
\hline 3 & De novo & + & ++ & ND & + \\
\hline 4 & De novo & + & + & + & +++ \\
\hline 5 & CML & 0 & 0 & + & ++ \\
\hline 6 & $\operatorname{Tr} 21$ & 0 & 0 & + & No growth \\
\hline 7 & De novo & 0 & $+1-$ & ND & No growth \\
\hline 8 & De novo & 0 & 0 & ND & ND \\
\hline 9 & De novo & ++ & ++ & + & No growth \\
\hline 10 & $\operatorname{Tr} 21$ & + & + & + & +++ \\
\hline 11 & CML & +++ & $+1-$ & + & +++ \\
\hline 12 & CML & ++ & $+1-$ & ND & +++ \\
\hline 13 & De novo & + & + & ND & + \\
\hline
\end{tabular}

CML, chronic myeloid leukemia; TR 21, constitutional trisomy 21. Quantification of RNA was estimated by the density of the specific band. For the primer in $5^{\prime}$, a precise quantification was made in five patients. It can be deduced that +++ correspond to $>500$ molecules $/$ cell; ++ to 30 molecules/cell; + to 0.5 molecules/cell. For primers in $3^{\prime}$ no precise quantification was performed and the number of + was given by comparison of the relative density of the specific bands. Epo receptors: $++, 1,000$ specific binding sites per cell;,$+>100$ specific binding sites per cell. Autonomous growth (plating efficiency):,$+++>1.0 \% ;++, 1.0 \% ;+,<1 \%$.

$1,2,4,5,6,11$, and 12) (16). The diagnosis of early erythroid leukemia was ascertained when differentiation markers showed the presence of CA1 and CD36 and, occasionally, GPA on blast cells and ferritin aggregates and $\theta$ granules were revealed by ultrastructural studies $(3,9)$. The percentage of blast cells was $>90 \%$ after Ficoll-metrizoate gradient separation of blood or marrow samples. There were three cases of erythroleukemic blast transformation of chronic myeloid leukemia, three cases of leukemias in patients with constitutive trisomy 21 , and seven cases of de novo leukemia. This study was performed either on fresh or frozen blood or marrow cells from patients since we were unable to derive continuous leukemic cell lines from these samples.

Semi-solid culture procedures. Cultures were maintained in serumfree medium using a previously described technique (21) applied to human cells (16). Briefly, the medium contained $1.5 \%$ deionized serum albumin (Cohn fraction V; Sigma Chemical Co., St. Louis, MO), ironsaturated human transferrin $(300 \mu \mathrm{g} / \mathrm{ml} ;$ Sigma $)$, calcium chloride (28 $\mu \mathrm{g} / \mathrm{ml}$ ), a mixture of sonicated lipids, $7.5 \times 10^{-4} \mathrm{M} \alpha$-thioglycerol, 100 $\mathrm{ng} / \mathrm{ml}$ insulin, and $0.8 \% 4,000$ chemically pure methylcellulose in Iscove's modified Dulbecco's medium. The lipid mixture was obtained by sonicating $7.8 \mathrm{mg}$ cholesterol, $6.14 \mathrm{mg}$ oleic acid, and $7.4 \mathrm{mg}$ dipalmitoyl lecithin (all obtained from Sigma) in $10 \mathrm{ml}$ of Iscove's modified Dulbecco's medium (without sodium bicarbonate) containing $1 \%$ serum albumin. $20 \mu \mathrm{l}$ of this mixture was used per milliliter of culture. Cultures were performed in triplicate in 1-ml vol in petri dishes (Corning Glass Inc., Corning, NY) with cell concentrations ranging from 5 $\times 10^{3}$ to $25 \times 10^{3}$ cells $/ \mathrm{ml}$. Cultures were incubated for 7 or $10 \mathrm{~d}$ in a fully humidified atmosphere with $5 \% \mathrm{CO}_{2}$. Colonies were counted under an inverted microscope.

Recombinant human (rh) Epo was purchased from Amersham, Les Ulis, France.

RNA blot hybridization. Total cellular RNA was isolated according to the method of Chomczynsky and Sacchi (22) from bone marrow or peripheral blood. Aliquots ( $20 \mu \mathrm{g}$ of RNA per lane) were size fractionated by means of formaldehyde/agarose gel electrophoresis and were then transferred to Hybond C-Extra membranes (Amersham). cDNA hybridization probes were labeled to a sp act of $1 \times 10^{9} \mathrm{cpm} / \mu \mathrm{g}$ by the random-priming method (23). The Epo probe was a 1,200-bp insert Epo cDNA clone into the SP65 plasmid (Genetics Institute, Cam- bridge, MA). To check for RNA integrity, membranes were rehybridized with a $\beta$-actin probe which gave positive results in all cases. After prehybridization, hybridization with the probes was performed for $48 \mathrm{~h}$ at $42^{\circ} \mathrm{C}$ in a hybridization buffer containing $50 \%$ formamide, $0.1 \% \mathrm{Na}$ Dod $\mathrm{SO}_{4}$ (SDS), $0.9 \mathrm{M} \mathrm{NaCl}, 50 \mathrm{mM} \mathrm{NaPO}_{4}, 5 \mathrm{mM}$ EDTA, $1 \times$ Denhart's solution, and $0.5 \mathrm{mg} / \mathrm{ml}$ salmon sperm DNA. Filters were washed four times in $2 \times$ standard saline citrate $(1 \times$ SSC: $150 \mathrm{mM}$ $\mathrm{NaCl} / 15 \mathrm{mM}$ sodium citrate, $\mathrm{pH} 7) / 0.1 \%$ SDS at room temperature and twice in $0.1 \times \mathrm{SSC} / 0.1 \% \mathrm{SDS}$ at $50^{\circ} \mathrm{C}$. Autoradiography was performed using Kodak X-OMAT AR film (Kodak Pathé, Marne La Vallée, France).

DNA blot hybridization. DNA $(10 \mu \mathrm{g})$ was digested with the restriction enzymes EcoRI, HindIII, BamHI, SstI, ScaI, and BstEII (Bethesda Research Laboratories, Gaithersburg, MD) in single or double digestion (24). The digests were size fractionated by means of electrophoresis in $1 \%$ agarose gels, and the gels were blotted to Hybond C-Extra membranes. The blots were hybridized, as previously described, with $\alpha^{32} \mathrm{P}$. labeled Epo cDNA probe (23). Blots were washed four times in $2 \times$ $\mathrm{SSC} / 0.1 \% \mathrm{SDS}$ at room temperature and three times in $0.1 \times \mathrm{SSC} / 0.1 \%$ SDS at $56^{\circ} \mathrm{C}$. Autoradiography was performed using Kodak X-OMAT AR film (Kodak Pathé).

Polymerase chain reaction (PCR). The PCR technique (25) was applied to RNA. A cDNA was synthesized directly in the amplification microtube by using $100 \mathrm{ng}$ of total denatured RNA in a 40- $\mu$ l reaction mixture containing $37.5 \mathrm{mM}$ Tris- $\mathrm{HCl}, \mathrm{pH} 8.3,187.5 \mathrm{mM} \mathrm{KCl}, 7.5$ $\mathrm{mM} \mathrm{MgCl}, 0.7 \mathrm{mM}$ dNTP, $0.03 \%$ (wt/vol) gelatin, $0.1 \mu \mathrm{g}$ of the respective antisense 3 ' PCR primer: CTTCCAGGCATAGAAATTAAC (nt 237 to nt 217) and CCCGGAGGAAATTGGAGTAGA (nt 532 to nt 512) (primers are numbered beginning at the Epo cDNA ATG codon, Adenosin being number 1 ) and $5 U$ of avian myeloblastosis virus reverse transcriptase (Promega Biotec, Madison, WI). The reaction mixture was incubated for $40 \mathrm{~min}$ at $42^{\circ} \mathrm{C}$. Two pairs of 21 -base oligonucleotides synthesized according to the published sequence of Epo cDNA $(26,27)$ were used in the PCR assays. One pair in $5^{\prime}$ was composed of a sense oligonucleotide GCCCCACCACGCCTCATCTGT (nt 82 to nt 102) and of an antisense CTTCCAGGCATAGAAATTAAC (nt 237 to nt 217) and gave a 412-bp DNA fragment and a 155-bp RNA fragment; the other located in $3^{\prime}$ included a sense 
TGGCCTTCGCAGCCTCACCAC (nt 381 to nt 401) and an antisense CCCGGAGGAAATTGGAGTAGA (nt 532 to nt 512) and gave a 286bp DNA fragment and a 152-bp RNA fragment. 20 pmol of each specific amplification primer, $2.5 \mathrm{U}$ of Taq polymerase (Perkin-Elmer Cetus, Norwalk, CT), and $\mathrm{H}_{2} \mathrm{O}$ (final vol $100 \mu \mathrm{l}$ ) were added to the reverse transcription reaction mixture. The final concentration of PCR buffer was $15 \mathrm{mM}$ Tris- $\mathrm{HCl} \mathrm{pH} 8.3,75 \mathrm{mM} \mathrm{KCl}, 3 \mathrm{mM} \mathrm{MgCl}, 0.3$ $\mathrm{mM}$ each $\mathrm{dNTP}$, and $0.015 \%$ (wt/vol) gelatin. The mixture was overlaid with mineral oil and amplified with a thermal cycler (Perkin-Elmer Cetus) according to the following protocol: 30 repeated cycles, including $1 \mathrm{~min}$ of denaturation at $94^{\circ} \mathrm{C}, 1 \mathrm{~min}$ of annealing at $55^{\circ} \mathrm{C}$ or $60^{\circ} \mathrm{C}$ with $5^{\prime}$ or $3^{\prime}$ primers, respectively, and $90 \mathrm{~s}$ of elongation at $72^{\circ} \mathrm{C}$. The components of the PCR were tested for contaminants by replacing RNA with $10 \mu 1 \mathrm{H}_{2} \mathrm{O}$.

Part (10\%) of the amplification product was analyzed on $2 \%$ agarose gel and hybridized with an appropriate internal oligonucleotide probe GAATATCACGACGGGCTGTG (nt 150 to nt 169) and CTCCGAACAATCACTGCTGAC (nt 469 to $\mathrm{nt} 489$ ) for the amplification in the $5^{\prime}$ end and the $3^{\prime}$ end, respectively, labeled by kinasing (23) with [ $\left.\lambda{ }^{32} \mathrm{P}\right]$ ATP and purified with NACS Prepac TH Cartridge (Bethesda Research Laboratories) after Southern transfer to Hybond C-Extra.

In addition, in patients 4 and 13 and in the HepG 2 cell line, large fragments ( $451 \mathrm{bp}$ and $523 \mathrm{bp}$ ) of the Epo mRNA were amplified. These amplification products included in the same fragment the previous amplified regions of the Epo mRNA and coded for 150 amino acid on 173 of the Epo molecule. cDNA was synthesized with $300 \mathrm{ng}$ (HepG2) or $2 \mu \mathrm{g}$ (patients) of total denatured RNA and $100 \mathrm{ng}$ of random hexadeoxynucleotide primers (Pharmacia, Saint-Quentin-enYvelines, France). Oligonucleotides used for the 451-bp RNA fragment amplification were the sense strand GCCCCACCACGCCT. CATCTGT (nt 82 to nt 102), and the antisense strand CCCGGAGGAAATTGGAGTAGA (nt 532 to nt 512). For the 523-bp RNA fragment the sense strand was CACGAATGTCCTGCCTGGCTG (nt 10 to nt 30), and the previous antisense strand. The internal oligonucleotide used to blot the amplification product was the first of the two previously described internal oligonucleotides (see above).

Quantitative PCR. Patients 2, 3, 4, 10, and 13 were studied for the quantitative PCR reaction (28). A 189-base RNA fragment was constructed; its two extremities contained complementary sequences to the two oligomers used for the amplification of the Epo transcript between the second and third exon. After amplification, its size ( $189 \mathrm{bp})$ is different from the normal amplified Epo transcript ( $155 \mathrm{bp}$ ) and allows a competitive PCR reaction. This synthetic RNA ( $10^{6}$ molecules) was mixed with increasing amounts of the test RNA. The PCR procedure was performed as described above; one-tenth of the amplification product was electrophoresed in an acrylamide gel that was stained with ethidium bromide and visualized under UV light. When the intensity of the two bands ( $155 \mathrm{bp}$ and $189 \mathrm{bp}$ ) was identical it was considered that the RNA sample contained $10^{6}$ Epo transcript copies.

In situ hybridization. Several molecular probes were used. The Epo probe used for in situ hybridization studies was a 720-bp insert of human Epo cDNA cloned into the pBS M13 plasmid (Stratagene Inc., La Jolla, CA). This probe covered the two RNA fragments in $5^{\prime}$ and $3^{\prime}$ which were studied by PCR. As positive and negative controls, we used a murine $\beta$-actin cDNA cloned into a transcription vector. As a negative control we used a $1.37-\mathrm{kb} \lambda$ phage DNA fragment cloned into a pGEM vector (Promega Biotec). Run-off transcripts of appropriate linearized plasmids were synthesized using T7, SP6, or T3 RNA polymerase in a reaction mixture containing $60 \mu \mathrm{Ci}\left[\alpha^{35} \mathrm{~S}\right] \mathrm{UTP}(1,200 \mathrm{Ci} /$ mmol; Amersham) according to the manufacturer's instructions (Promega Biotec), except that unlabeled UTP was omitted to achieve synthesis of the RNA probe with a sp act of $10^{9} \mathrm{cpm} / \mu \mathrm{g}$. The fragment length of the RNA probes was adjusted to an average of $\sim 100-150$ bases by limited alkaline hydrolysis (29). The RNA probes were of similar specific activity and size (determined by gel electrophoresis under denaturing conditions). Fixation, hybridization, and stringent washes were carried out as previously described (29-31), with some modifications. The cells were cytocentrifuged and immediately fixed in
4\% paraformaldehyde in PBS, $\mathrm{pH} 7.4$, for $3 \mathrm{~min}$ at room temperature. Preparations were then transferred to $70 \%$ ethanol and stored at $4{ }^{\circ} \mathrm{C}$ until use. At this point, negative control slides were treated with 100 $\mu \mathrm{g} / \mathrm{ml} \mathrm{RNase} \mathrm{A} \mathrm{(Sigma)} \mathrm{in} 2 \times \mathrm{SSC}$ for $2 \mathrm{~h}$ at $37^{\circ} \mathrm{C}$. The slides were postfixed in $2 \%$ paraformaldehyde/1\% glutaraldehyde in PBS for 7 min, washed in PBS, acetylated, washed in PBS, dehydrated in ethanol, and air dried. RNA probes were ethanol precipitated with yeast tRNA and salmon sperm DNA and washed with $70 \%$ ethanol. The dried pellets were resuspended in the hybridization buffer to give final concentrations of $50 \%$ deionized formamide, $0.3 \mathrm{M} \mathrm{NaCl}, 20 \mathrm{mM}$ Tris$\mathrm{HCl}$ (pH 8), 0.5 mM EDTA, $1 \times$ Denhardt's solution, $10 \%$ dextran sulfate, $20 \mathrm{mM}$ dithiothreitol, $500 \mu \mathrm{g} / \mathrm{ml}$ yeast tRNA, $1 \mathrm{mg} / \mathrm{ml}$ salmon sperm DNA, and $10^{8} \mathrm{cpm} / \mathrm{ml}$ of the RNA probe. The hybridization mixture was denatured and applied to the slides. Hybridization was performed at $50^{\circ} \mathrm{C}$ for $20 \mathrm{~h}$ in a humidified chamber. The slides were successively washed at $54^{\circ} \mathrm{C}$ three times in $2 \times \mathrm{SSC} /$ dithiothreitol $(10$ $\mathrm{mM}$ ), three times in the same buffer plus $50 \%$ formamide, and three times in $2 \times \mathrm{SSC} /$ dithiothreitol $(1 \mathrm{mM})$, followed by RNase digestion. After a second series of washings, the slides were successively rinsed in decreasing concentrations of SSC with $1 \mathrm{mM}$ dithiothreitol, dehydrated in ethanol, air dried, and coated with NTB2 emulsion (International Biotechnologies, Inc., A Kodak Co., New Haven, CT) for autoradiography. After $15 \mathrm{~d}$ of exposure, the slides were developed in Dektol (Kodak Pathé), fixed in Unifix (Kodak Pathé), and stained with MayGrunwald Giemsa. The number of silver grain per cell was counted and the cells were categorized according to the number of silver grain. More than 200 cells were counted per slide per experiment.

Cells from two patients were subjected to in situ hybridization in at least three separate experiments. In addition to the positive ( $\beta$ actin) and negative ( $\lambda$ phage) control probes and ribonuclease-pretreated slides, two positive controls (an Epo cDNA transfected CHO cell line and the HepG2 cell line) for the Epo probe were included.

Epo receptor characterization. The methods used for binding studies have been fully described elsewhere $(32,33)$. With the exception of one patient, the presence of Epo receptors was ascertained by binding of ${ }^{125}$ I Epo to $2 \times 10^{6}$ cells. Nonspecific binding was measured using the same method except that a 100-fold excess of unlabeled Epo was added to the ${ }^{125} I$ Epo. A Scatchard analysis was performed in one case. Briefly, highly purified rhEpo was iodinated to a sp act of $750 \mathrm{Ci} / \mathrm{mmol}$ using the iodogen method. Binding $\left(2 \mathrm{~h}\right.$ at $\left.37^{\circ} \mathrm{C}\right)$ was initiated by the addition of $1.5 \times 10^{6}$ cells in $100 \mu$ l of Eagle's MEM containing 10\% FCS and $0.02 \%$ sodium azide and various concentrations of labeled Epo in the presence or absence of excess (at least 100X) unlabeled Epo. Cells were then washed three times with ice-cold PBS and cell-associated radioactivity was measured by $\gamma$ counting. Specifically bound radioactivity was calculated by subtracting the radioactivity associated with cells incubated with an excess of unlabeled Epo (nonspecific radioactivity) from that of cells incubated with labeled Epo only (total radioactivity). Results of equilibrium experiments were analyzed according to Scatchard's method using unweighted least-square linear regression fitting.

Antisense oligonucleotides. Several unmodified 15-base oligonucleotides were made using a DNA synthesizer (Applied Biosystems, Inc., Foster City, CA) and purified either by two ethanol precipitation steps and multiple washes in $80 \%$ ethanol, or by migration in a urea/ polyacrylamide gel, followed by electroelution and ethanol precipitation. After evaporation to dryness the oligonucleotides were dissolved in PBS. We used two 15-mer Epo antisense oligomers complementary to the first exon (GTGCACCCCCATCTC, nt 12 to $\mathrm{nt}-3$, and CACCCCCATCTCCGC, nt 9 to $\mathrm{nt}-6$ ). A positive control, a c-myb antisense oligomer (GTGCCGGGGTCTTCGGGC, nt 21 to nt 3) (34), and a negative control, an Epo sense oligomer (GAGATGGGGGTG$\mathrm{CAC}$ nt -3 to $\mathrm{nt} 12$ ), were used in these experiments.

These oligomers were incubated in serum-free culture medium devoid of methylcellulose for $3 \mathrm{~h}$ at $37^{\circ} \mathrm{C}$. Methylcellulose was then added and the cells were cultured normally with a final oligomer concentration of $10 \mu \mathrm{M}$. In preliminary experiments, oligomer concentrations ranging from $1 \mu \mathrm{M}$ to $50 \mu \mathrm{M}$ in $1-\mathrm{ml}$ petri dishes were tested. 
Anti-Epo antibody. A polyclonal antibody against Epo was obtained by immunizing rabbits with rhEpo. IgG was then isolated using protein-A/Sepharose chromatography (Pharmacia, France). 1-20 $\mu$ l of anti-Epo IgG (3 mg/ml, neutralizing 2-40 U of Epo) was added to each culture dish. The same amount of IgG from nonimmunized rabbits was used as a control.

Epo radioimmunoassay. Cells were cultured for $2-7 \mathrm{~d}$ in serum-free liquid medium at a concentration of $10^{6}$ cells per $\mathrm{ml}$. The medium was then recovered and concentrated 10 -fold by means of ultrafiltration. Epo was detected using a radioimmunoassay, as previously described (35), with ${ }^{125}$ I rhEpo as tracer. Briefly rabbit polyclonal antibody specific to Epo was incubated overnight at $4^{\circ} \mathrm{C}$ with the conditioned medium. Antibody-bound ${ }^{125}$ I Epo was then separated from free ${ }^{125}$ I Epo by the addition of Tachisorb (goat IgG against rabbit IgG and conjugated to Staphylococcus aureus; Calbiochem Corp., La Jolla, CA).

\section{Results}

Patients. 13 patients with early erythroid leukemia were studied (Table I). Their blood or marrow contained $>90 \%$ of blast cells. The in vitro growth characteristics of leukemic cells from patients $1,2,4,5,6,11$, and 12 have previously been described in detail (16). Except for four patients, two with Down's syndrome (patients 1 and 6) and patients 7 and 9, blood or marrow cells formed leukemic erythroid colonies when cultured in the presence of Epo or granulocyte macrophage colony-stimulating factor (GM-CSF). Some colonies were atypical and their erythroid nature was ascertained by the presence of CA1 and GPA $(3,16)$. In 8 of the 13 cases, colonies were observed in the absence of added stimuli, the absolute number of colonies was increased in the presence of Epo or GM-CSF.

Northern blot and Epo radioimmunoassay. Northern blotting and radioimmunoassay were used to investigate a possible Epo gene transcription and protein secretion by the leukemic cells. As shown in Fig. 1, Epo transcripts of the expected size $(1.4 \mathrm{~kb})$ were observed only with mRNA from patient 2 (Fig. 1 ). Blots were subsequently hybridized with a $\beta$-actin probe to ensure that undegraded and roughly equivalent amounts of mRNA were present in the different samples (data not shown). Cells from these patients were cultured in unstimulated liquid cultures for $7 \mathrm{~d}$. Radioimmunoassay performed on the supernatant medium revealed the presence of $25 \mathrm{mU} / \mathrm{ml}$ of Epo in the culture medium from patient 2, while no Epo could be detected in cultures of the remaining patients $(1,3,4,5,6,11$, and 12).

$P C R$. To detect low Epo transcription levels by leukemic cells, a PCR technique with two different pairs of primers was used. One set of primers was located at the $5^{\prime}$ end (nt 82 to $\mathrm{nt}$ 237) and the other at the $3^{\prime}$ end (nt 381 to nt 532) of the Epo cDNA. To distinguish RNA from DNA amplification products, primers were chosen in different exons (exons two and three, and exons four and five, respectively). The sizes of the

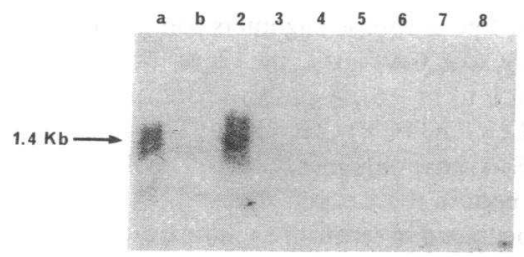

Figure 1. Identification of Epo transcripts by Northern blotting. Total RNA $(20 \mu \mathrm{g})$ was applied to each lane. Membranes were hybridized with $\alpha^{32} \mathrm{P}$ Epo cDNA. (Lane $a$ ) Fetal

liver ( $8 \mathrm{wk}$ ). (Lane $b$ ) Normal activated lymphocytes. Lanes 2-8 correspond to the patient numbers in Table I. A transcript of $1.4 \mathrm{~kb}$ was detected in the fetal liver $(a)$ and in patient 2 .

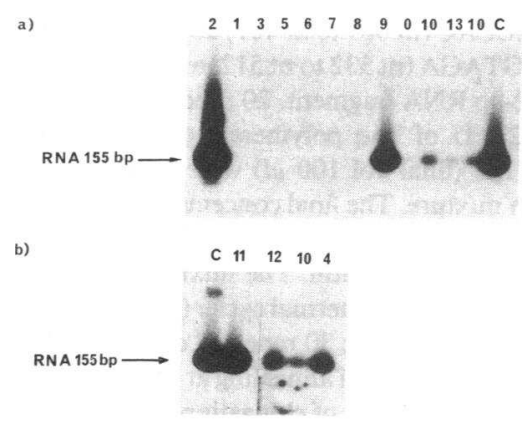

Figure 2. Reverse-transcribed PCR for Epo transcripts with the pair of oligomers located at the $5^{\prime}$ end of the Epo gene. $a$ and $b$ are two independent experiments. The numbers at the top of each lane refer to the patients. $C$ is a positive control (RNA from HepG2 cells). 0 is a negative

control (RNA replaced by water). Total RNA (100 ng) was reverse transcribed with the antisense oligomer (Epo $\left.5^{\prime}\right)$ and then submitted to 30 amplification cycles with the pair of oligomers located at the 5 ' end of the Epo gene. Part (10\%) of the amplification product was analyzed by Southern blotting with a specific oligomer. The size of the amplified RNA is $155 \mathrm{bp}$. In patient 3 the detection of the amplification product required a longer exposure time than for the other patients.

amplified DNA and RNA were 412 bp and 155 bp for the $5^{\prime}$ set of primers, and $286 \mathrm{bp}$ and $152 \mathrm{bp}$ for $3^{\prime}$ set of primers, respectively. After agarose gel electrophoresis, the amplification products were hybridized with specific oligonucleotide probes.

As in the Northern blot analysis, Epo transcripts were detected in cells from patient 2 by means of PCR analysis using both sets of primers (Figs. 2 and 3). Moreover, Epo transcripts were also detected in samples from the seven other patients (3, $4,9,10,11,12$, and 13) (Fig. 2) which were negative by Northern analysis. Reproducible quantitative differences in the amount of Epo transcripts were observed between the various patients' samples, and in patients 3,10 , and 13 , levels were at the threshold of detection. Results with the two pairs of primers were similar in repeated experiments (Figs. 2 and 3). We observed that RNA from patients 11 and 12 gave larger amounts of amplification products with the two 5 ' primers than with the 3 ' primers (Figs. 2 and 3), while for the other patients very slight differences between the two sets of primers were observed. This could be related to the presence of incompletely transcribed mRNA. To demonstrate that the two amplification products in $5^{\prime}$ and $3^{\prime}$ were located on the same RNA, large fragments of the Epo mRNA (451 bp and $523 \mathrm{bp}$ ) were amplified from samples prepared from patients 4 and 13 . These two large fragments included almost the entire coding region for the Epo cDNA. As shown in Fig. 4, these two fragments were present in cells from both patients, demonstrating that the two small size amplification products in $5^{\prime}$ and $3^{\prime}$ were derived from a fully transcribed mRNA.

A more precise quantitative analysis was performed by means of competitive PCR using the $5^{\prime}$ set of primers as above

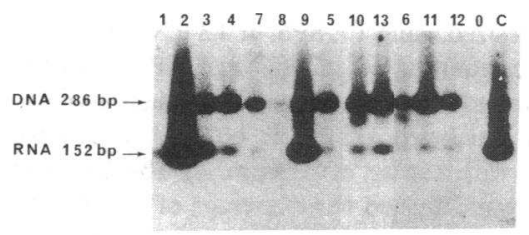

Figure 3. Reverse-transcribed PCR for Epo transcripts with the pair of oligomers located at the $3^{\prime}$ end of the Epo gene. The numbers at the top of each lane refer to the patients. $C$

is the positive control (RNA from HepG2 cells); $O$ is a negative control (RNA replaced by water). The size of the amplified DNA fragment is $286 \mathrm{bp}$, and that of the RNA fragment $152 \mathrm{bp}$. 


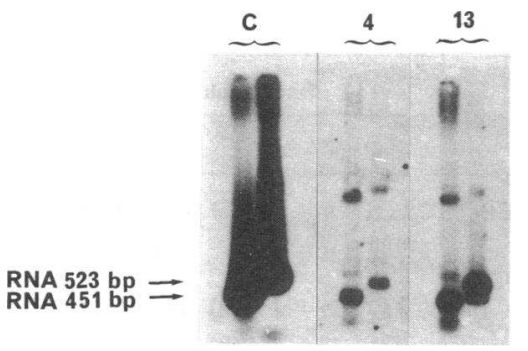

Figure 4. Autoradiogram of 451-bp and 523-bp RNA large fragment amplification products in patients 4 and 13 and in the HepG2 cell line positive control $(C)$. Hybridization with a labeled internal oligonucleotide (nt 150 to nt 169 ) demonstrate that the two small size amplification products in $5^{\prime}$ and $3^{\prime}$ end of the Epo gene were derived from the same RNA.

and a synthetic Epo mRNA of a different size (28) (Fig. 5). The amount of Epo transcripts varied from 500 per cell in patient 2 to 0.5 per cell in patient 10 , i.e., the threshold of sensitivity (five patients were analyzed, Table I). The same quantitative study was not performed with the $3^{\prime}$ primers.

Contamination was checked for in all experiments by omitting RNA extracts from the amplification mixtures in at least one tube.

In situ hybridization. To verify that Epo transcription was related to erythroid leukemic cells and not to normal blood or marrow contaminant cells, we performed in situ hybridization experiments. Only patients 2 and 4 were investigated since cells from the former clearly synthesized Epo, while Epo transcripts were only detected by PCR in the latter.

In patient 2 , almost all the blast cells were labeled by the ${ }^{35} \mathrm{~S}$-Epo riboprobe (Figs. 6 and 7). The rare contaminant monocytes and mature erythroid cells which were also present in the sample, did not hybridize with this probe. The number of grains per blast cell was on average fivefold higher than in the control ( $\lambda$ phage). No hybridization occurred after pretreatment of the slides with RNase. In patient 4 , the histogram of the silver grain distribution showed that only a fraction of the blast cells $(\sim 15 \%)$ displayed a number of silver grain higher than the negative control value. Chinese hamster ovary cells transfected with the Epo gene and the HepG2 cell line were used as positive controls for Epo expression.

Southern blot. As blast cells from patients 2 and 9 expressed the highest amounts of Epo transcripts, the integrity of the Epo gene was checked by Southern blot analysis. Using several restriction enzymes that cut outside the Epo transcription unit

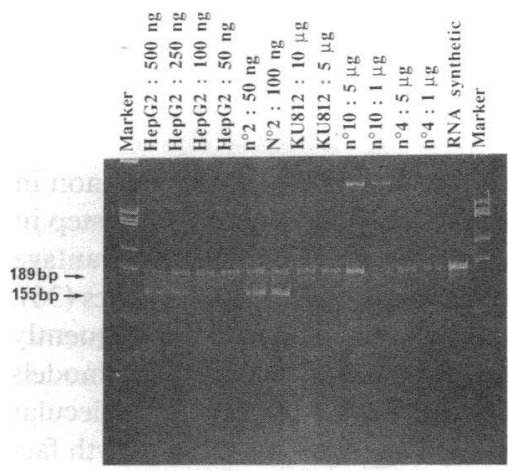

Figure 5. Competitive PCR for Epo transcripts. The same primers and techniques as in Fig. 2 were used. A 189-bp synthetic Epo RNA was constructed and added at a concentration of $10^{6}$ copies per amplification tube. RNA from each patient and from two cell lines (HepG2 and KU 812 cells) were used at dilutions from $50 \mathrm{ng}$ to 10

$\mu \mathrm{g}$. The intensity of the 189-bp band (synthetic Epo transcript) and of the 155-bp band (normal Epo transcript) were compared under UV light. The total RNA content per cell was calculated from the RNA extraction of $20 \times 10^{6}$ cells in each case.
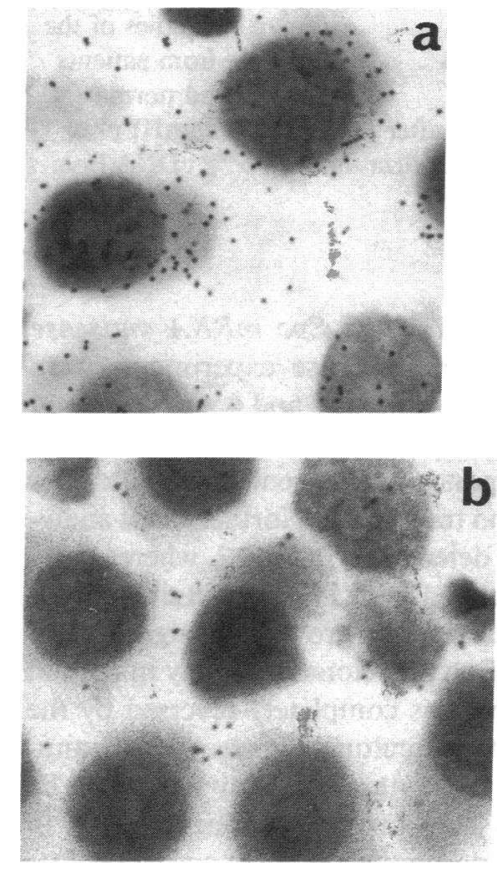

Figure 6. Detection of Epo transcripts in blast cells from patient 2 by in situ hybridization. (a) Cells hybridized with the ${ }^{35} \mathrm{~S}$ Epo probe. (b) Cells hybridized with the ${ }^{35} \mathrm{~S} \lambda$ probe. $\times 400$.

(EcoRI, HindIII, BamHI, EcoRI plus HindIII, EcoRI plus BamHI, BamHI plus HindIII) or within it (SstI, BstEII, and ScaI and SstI plus BstEII) no differences with the restriction pattern obtained with normal cells were seen (Fig. 8).

Epo receptors. Epo receptor expression was investigated in nine patients by labeling the cells with ${ }^{125} \mathrm{I}$ Epo. In patients 3 and 12, a low binding level was detected but no competitive studies with unlabeled Epo could be performed due to a lack of cells. The presence of Epo receptors was clearly demonstrated in seven other patients. The number of Epo receptors per cell was always lower than that obtained with cells from patient 2 and was estimated to range from 300 to 400 receptors per cell. Patient 2 was studied in more detail since a large number of cells was available. Scatchard analysis revealed 1,000 sites per cell of a single-class Epo receptor $\left(K_{\mathrm{d}}: 420\right.$ pM) (Fig. 9, $a$ and $b$ ).
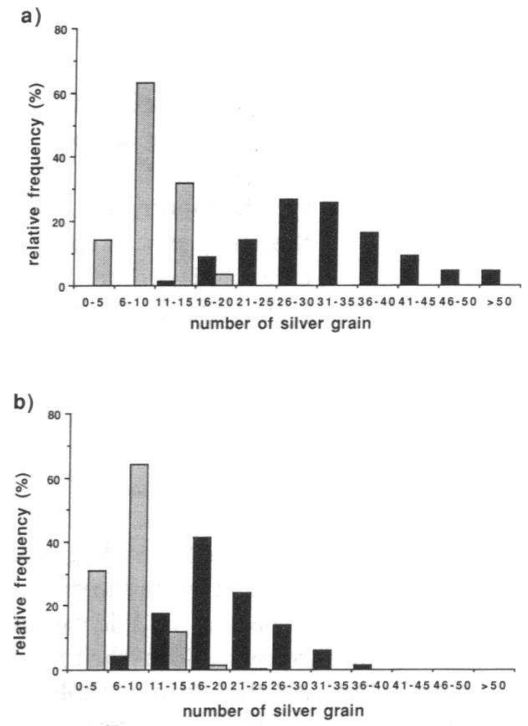

Figure 7. Silver grain distribution in blast cells from patients $2(a)$ and $4(b)$ after in situ hybridization with ${ }^{35} \mathrm{~S}$ Epo and negative $\lambda$ control RNA probes. The histogram in black corresponds to the Epo probe and the grey one to the $\lambda$ probe. Cells were examined under light microscopy $(\times 400)$ and the mean number of silver grain per blast cell was determined. The number of cells with a given number of silver grain was scored into one of the classes of silver grain fixed arbitrarily. The

frequency of cells in each class was calculated after having examined 200 cells. 


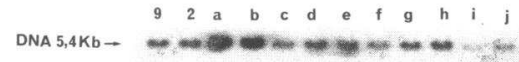

Figure 8. Studies of the Epo gene from patients 2 and 9 and normal

controls $(a-j)$ by Southern blotting after digestion by BamHI plus HindIII restriction enzymes and hybridization with $\alpha^{32} \mathrm{P}$ cDNA Epo. The size of DNA fractions was $5.4 \mathrm{~kb}$.

Effects of anti-Epo antibodies and Epo mRNA antisense oligomers on spontaneous growth. These experiments were carried out only with cells from patients 2 and 4 which showed two apparently different pathways of autocrine stimulation. Cells from both patients responded to exogenous Epo and thus expressed Epo receptors. Epo transcripts (Northern blot analysis) and Epo secretion were detected in patient 2, whereas Epo transcripts could only be detected using PCR and in situ hybridization in patient 4 . Spontaneous cell growth was significantly inhibited (78\%) by an anti-Epo polyclonal antibody in patient 2 (Table II). This inhibition was completely reversed by the addition of exogenous Epo to the cultures. Moreover, this antibody specifically inhibited the erythroid colony formation by normal bone marrow cells grown in the presence of Epo. In contrast, this antibody had no significant effect on the spontaneous growth of cells from patient 4 (Table II). Other patients were not tested. As Epo autocrine stimulation could occur inside the cells, we studied the effects of two Epo mRNA antisense oligomers on autonomous growth (Table II). Since the effects of antisense oligonucleotides are usually related to degradation of RNA by RNaseH, we used a PCR technique to investigate whether Epo transcription was diminished after antisense treatment. Cells from patient 2 were studied since Epo transcripts were present in large amounts and easily detectable on a low number of cells. An identical number of cells from this patient were incubated overnight in serum-free conditions with each one of the antisense Epo oligonucleotides and with the sense oligonucleotide as a control. Cells were recovered and a

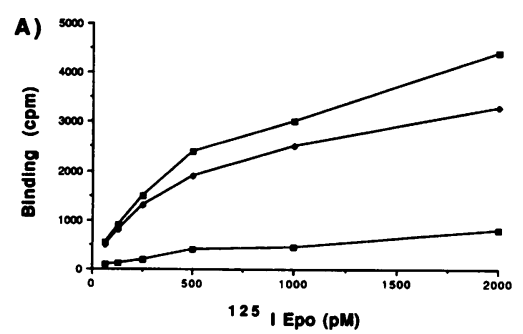

Figure 9. Presence of Epo receptors on blasts cells from patient 2. $(A)$ Binding of ${ }^{125}$ I-Epo to erythroleukemic cells. Total binding ( $(\bullet)$, nonspecific binding (), specific binding (४). (B) Scatchard plot of specific binding. Blood cells $\left(1.5 \times 10^{6}\right)$ from patient 2 composed of $95 \%$ erythroid blasts were incubated in $200 \mu$ l of alpha medium and various concentrations of ${ }^{125} \mathrm{I}$ Epo for $2 \mathrm{~h}$ at $37^{\circ} \mathrm{C}$. Nonspecific binding was determined in the presence of a 100-fold excess of unlabeled Epo. Nonspecific binding was substracted from the total binding to obtain the specific binding. Data are the mean of triplicates. The binding data $(A)$ were plotted by the method of Scatchard $(B)$. A single class of Epo receptors $\left(K_{\mathrm{d}}: 420 \mathrm{pM}\right)$ was detected and cells bound 1,000 molecules of ${ }^{125}$ I-Epo.
Table II. Effect of EPO Antibody and Antisense EPO RNA

\begin{tabular}{lccccc}
\hline & \multicolumn{4}{c}{ Percent inhibition } \\
\cline { 2 - 6 } & \multicolumn{2}{c}{ Patient 2 } & \multicolumn{2}{c}{ Patient 4 } \\
\hline Polyclonal antibody against EPO & $78 \pm 8$ & $n=3$ & $10 \pm 10$ & $n=3$ \\
Control IgG & $12 \pm 3$ & $n=3$ & 0 & $n=2$ \\
EPO antisenses & 37 & $n=1$ & (a) $43 \pm 9$ & $n=5$ \\
& & & (b) $51 \pm 28$ & $n=3$ \\
EPO sense & 0 & $n=1$ & $16 \pm 15$ & $n=3$ \\
c-myb antisense & ND & & $59 \pm 15$ & $n=5$
\end{tabular}

Cultures were performed in serum-free medium in triplicate. Cells were plated at concentration of $25 \times 10^{3} \mathrm{cell} / \mathrm{ml}$ and $1 \times 10^{4} \mathrm{cells} / \mathrm{ml}$ for patients 2 and 4, respectively. Two Epo antisense oligomers ( $a$ and b) differing by three nucleotides (see Methods) were incubated with the cells at $10 \mu \mathrm{M}$. Controls were two sense oligomers complementary of the two antisenses; results were similar with both and the results were pooled. In each experiment, the number of colonies per dish in the controls ranged from 80 to 250 . Variability was $\sim 10 \%$ among identical dishes. The two means between antisense and sense oligomers were significantly different by Student's $t$ test $(0.02<P$ $<0.01) . n=$ Number of experiments.

PCR technique was directly applied on the cell lysate using the $3^{\prime}$ set of primers. A marked decrease in the amount of Epo transcripts was observed for cells treated with the two Epo antisense oligomers in comparison to cells treated with the control oligomer. Indeed, the amplification product became barely detectable after antisense treatment, and was just over the threshold of the technique (data not shown). In eight separate experiments, the autonomous growth of cells from patient 4 was significantly inhibited (from $34 \%$ to $84 \%$ ) by these oligomers in comparison to values obtained with the sense oligomer ( $6 \%$ to $34 \%$ ). The inhibitory effect was totally reversed by the addition of exogenous Epo to the cultures since the number of colonies observed was similar as in cultures with Epo alone (data not shown). As a positive control for the Epo antisense oligomers, we included in our experiments a c-myb antisense (34). This oligomer induced a similar inhibition (36 to 74\%)(Table II). In contrast, the inhibition observed with the Epo antisense was moderate in patient 2 . This may be due to the large amount of Epo transcripts that could not be totally inhibited by antisense treatment.

\section{Discussion}

Growth factor autonomy appears to be a key phenomenon in the process of tumorigenesis. It may either be an early step in leukemic transformation leading to a proliferative advantage or a mechanism transforming factor-dependent cell lines (36). Partial or total autonomy from exogenous Epo is frequently observed in erythroid malignancies both in animal models (18-20) and in man (10-12). At least three distinct molecular mechanisms can give rise to independence from a growth factor: $(a)$ endogenous production of growth factor; $(b)$ alteration of growth factor receptors; $(c)$ alteration of the signaling pathway normally induced by the interaction of the growth factor with its specific receptor. In animal models, the most frequent mechanism responsible for Epo autonomy or Epo hyperre- 
sponsiveness involves alteration of growth factor receptors such as v-erb B in chicken (37) and v-fms in mice (38). However, other mechanisms involving Epo or its receptor may be responsible for this autonomy. In murine Friend cells, the interaction of $\mathrm{Gp} 55$ (the envelope glycoprotein of the Friend virus) with the Epo receptor leads to a continuous activation of the receptor in the absence of the normal ligand (19-20). Transformation of erythroid cells by the Friend virus may be associated with synthesis and secretion of Epo, suggesting an autocrine process of transformation $(39,40)$. However, the precise role of Epo in this malignant transformation remains unclear since the autonomous proliferation is not blocked by antiEpo neutralizing antibodies (our unpublished results).

In this study, we investigated 13 cases of human erythroleukemia in search of an autocrine stimulation by Epo. In most patients (7/13), Epo receptors were found on the cell surface in binding experiments with ${ }^{125}$ I Epo. The number of Epo receptors was not markedly different from that of normal erythroid progenitors since it never exceeded 1,000 per cell. Thus, autonomy of the leukemic cells from growth factors was not apparently related to an overexpression of Epo receptors. We subsequently investigated the endogenous production of Epo. In only one case, Epo transcripts and protein were clearly detected by Northern blotting and radioimmunoassay, respectively. However, using PCR analysis, we found Epo transcripts in 8 cases out of 13. The number of Epo transcripts present in each cell, estimated using a competitive PCR technique, ranged from 500 to 0.5 (the latter value being the threshold of detection). It has been calculated that eight molecules of Epo were sufficient to induce proliferation and differentiation of erythroid cells (41). Therefore, since in situ hybridization showed that a fraction of the blast cell expressed Epo mRNA and since each transcript can be translated into several copies, an average number of Epo transcripts as low as 0.5 per cell is compatible with an autocrine stimulation. However, the detection of Epo transcripts by PCR or in situ hybridization does not exclude the possibility that the Epo transcript is incomplete or untranslated into protein. We tried to minimize this possibility by comparing results obtained with two pairs of primers located in the second and third exons and in the fourth and fifth exons, respectively. Some differences were observed but, with the exception of two patients, these differences were very slight, suggesting that a complete mRNA transcript was synthesized. We tried to amplify a full-length Epo mRNA from the HepG2 cell line but we were unable to perform such an amplification. However, we succeeded in amplifying two large RNA fragments which included the two previously amplified RNA fragments and almost the entire coding region of the Epo cDNA. Two patients were selected for this study since they expressed low amounts of Epo transcripts in the quantitative study. In both cases, these two large Epo mRNA fragments were detected. Therefore, it seems very unlikely that an incomplete Epo transcription was present in these patients.

It is usually thought that only cells located in the kidney and liver synthesize Epo, but the precise cell type remains controversial (42-44). However, some data suggest that marrow macrophages also produce Epo (45). Using PCR, we have detected small amounts of Epo transcripts in several cell types including both normal marrow and blood cells (our unpublished data), although the significance of these findings is not known since, in most cases, the number of Epo transcripts was at the threshold of detection. To determine whether Epo was synthesized by a contaminant cell in the erythroleukemia samples, we performed in situ hybridization in two cases ( 2 and 4 ) and found that blast cells expressed Epo transcripts. The molecular mechanisms responsible for this Epo synthesis by erythroid blasts are unknown. In the two patients studied, we were unable to detect Epo gene abnormalities by Southern blotting using several restriction enzymes. This suggests that there was no major abnormality in the Epo gene, although point mutations inside the gene or abnormalities in distant regulatory regions cannot be excluded. "Aberrant" growth factor synthesis has been attributed both to an alteration in the growth factor gene (46), and the activation of an oncogene such as Ras (47). However, synthesis of Epo by erythroid cells may well be reminiscent of a phenomenon that occurs during normal erythropoiesis either after cytokine stimulation or during ontogenesis. This phenomenon has previously been reported for GM-CSF which is involved in autocrine regulation not only in many acute myelogenous leukemias $(48,49)$ but also in normal immature myeloid cells stimulated by IL-1 (50).

Finally, we tried to determine the precise role of Epo synthesis in the growth factor autonomy of the leukemic cells. The search for a correlation between Epo gene transcription, expression of Epo receptors, and spontaneous erythroid colony formation gave unclear results. Indeed, Epo transcripts were not detected in all the patients with spontaneous erythroid growth and, conversely, Epo transcripts were present in blast cells from patients with no spontaneous erythroid growth in vitro. Studies were subsequently focused on two patients to determine the role of endogenously produced Epo in autonomous growth. Anti-Epo antibodies blocked autonomous growth only in the patient whose blast cell supernatant contained Epo. In the other case, it could not be ruled out that the low amount of Epo produced stimulated growth by binding to the receptor inside the cell. An intracellular stimulation by growth factor has been hypothesized in several growth factorindependent cell lines (51) and has been demonstrated in an IL-3-dependent cell line by transferring an IL-3 cDNA modified by the addition of a retention signal that prevents secretion of growth factor (52). Furthermore, recent data have suggested that in the Friend disease, activation of Epo-independent cell growth is related to binding of Gp55 to Epo receptors in the endoplasmic reticulum (20). To address this question, we analyzed the effects of Epo antisense oligomers. The inhibitory effect on erythroid proliferation was significantly greater than with the control sense oligomer. However, this oligomer led to some degree of inhibition in comparison to untreated cells. It is noteworthy that despite the presence of an autocrine intracellular Epo stimulation, cells from this patient also respond to exogenous Epo. Therefore it cannot be excluded that the growth of these leukemic cells is also stimulated in vivo by an Epo extracellular signal.

In conclusion, our results throw light on the involvement of Epo in the autonomous growth of human erythroleukemic cells. Epo transcription occurred in most cases (8/13) and, in one case, antibody blocking experiments showed clearly that Epo was involved in an external process of autocrine stimulation. In another case, RNA antisense oligomer experiments suggested that this process may occur inside the cell. It therefore appears that Epo synthesis is one of the mechanisms accounting for autonomous growth in human erythroleukemia and that its effect may be internally mediated. Previous data in mice have shown that dysregulated production of hematopoi- 
etic growth factors, including Epo, in normal hematopoietic cells (53-56), transgenic mice (57), or after retroviral gene transfer in stem cells (our unpublished results) does not give rise to leukemia. It was suggested that autocrine stimulation must be associated with other genetic events to induce leukemic transformation. Nevertheless, these models essentially describe the results of a hypersecretion of these growth factors and it is not known whether internal action leads to the same effect in normal cells. Work is in progress to identify the other molecular events leading to autonomous growth in erythroleukemia and to determine the precise effects of internal autocrine stimulation on normal cells.

\section{Acknowledgments}

We are grateful to Genetics Institute, Cambridge, MA, for the generous gift of the Epo cDNA, to Dr. F. Dautry, Villejuif, France, for $\beta$ actin cDNA, and to Dr. P. Mayeux, Paris, France, for the preparation of rabbit Epo IgG. We thank A. M. Dulac and V. Corsetti for typing the manuscript, and J. M. Massé for photographic assistance. We are indebted to F. Bernaudin, Créteil, France, and F. Teillet, Colombe, France, for providing patient samples, to $\mathrm{P}$. $\mathrm{H}$. Roméo for helpful discussion, and to $P$. Duquesnoy for his advice concerning the molecular biology. We also thank F. Wendling for critical review of the manuscript and D. Young for improving the English.

This work was supported by grants from la Ligue Nationale contre le Cancer, Groupements des entreprises francaises dans la lutte contre le cancer, and Fondation contre la leucémie. M. T. Mitjavila has a fellowship from la Fondation de France, Institut National de la Santé et de la Recherche Médicale-Consejo Superior de Investigacion Cientifica cooperation.

\section{References}

1. Adamson, J. W., P. J. Fialkow, S. Murphy, J. F. Prchal, and L. Steinman 1976. Polycythemia vera: stem cell and probable clonal origin of the disease. $N$ Engl. J. Med. 295:913-916.

2. Bennet, J. M., D. Catovsky, M. T. Daniel, G. Flandrin, D. A. G. Galton, H. R. Gralnick, and C. Sultan. 1976. Proposals for the classification of the acute leukaemias. Br. J. Haematol. 33:451-458.

3. Villeval, J. L., P. Cramer, F. Lemoine, A. Henri, A. Bettaieb, F. Bernaudin, Y. Beuzard, R. Berger, G. Flandrin, J. Breton-Gorius, and W. Vainchenker. 1986. Phenotype of early erythroblastic leukemias. Blood. 68:1167-1174.

4. Greaves, M. F., C. Sieff, and P. A. W. Edwards. 1983. Monoclonal antiglycophorin as a probe for erythroleukemias. Blood. 61:645-651.

5. Anderson, L. C., C. G. Gahmberg, L. Teerenhovi, and P. Vuopio. 1979. Glycophorin A as a cell surface marker of early erythroid differentiation in acute leukemia. Int. J. Cancer. 23:717-720.

6. Liszka, K., O. Majdic, P. Bettelheim, and W. Knapp. 1983. Glycophorin A expression in malignant hematopoiesis. Am. J. Hematol. 15:219-226.

7. Koike, T., E. Takakuwa, and A. Shibata. 1990 . Early erythroblastic leukemia presenting as de novo acute leukemia. Leukemia and Lymphoma. 1:147151.

8. Vuillet-Gaugler, M. H., J. Breton-Gorius, W. Vainchenker, J. Guichard, C. Leroy, G. Tchernia, and L. Coulombel. 1990. Loss of attachment to fibronectin with terminal human erythroid differentiation. Blood. 75:865-873.

9. Breton-Gorius, J., J. L. Villeval, M. T. Mitjavila, G. Vinci, J. Guichard, H. Rochant, G. Flandrin, and W. Vainchenker. 1987. Ultrastructural and cytochemical characterization of blasts from early erythroblastic leukemias. Leukemia (Baltimore). 1:173-181.

10. Prchal, J. F., and A. A. Axelrad. 1974. Bone marrow responses in polycythemia vera. N. Engl. J. Med. 290:1382.

11. Lacombe, C., N. Casadevall, and B. Varet. 1980. Polycythemia vera: in vitro studies of circulating erythroid progenitors. Br. J. Haematol. 44:189-199.

12. Eaves, C. J., and A. C. Eaves. 1979. Erythropoietin (E.P.) dose-response curves for three classes of erythroid progenitors in normal human marrow and in patients with polycythemia vera. Blood. 52:1196-1210.

13. Eridani, S., M. Dudley, M. Sawyer, and T. C. Pearson. 1987. Erythropoietic colonies in a serum free system: results in primary polycythaemia and thrombocythaemia. Br. J. Haematol. 67:387-391.

14. Zanjani, E. D., J. D. Lutton, R. Hoffman, and L. R. Wasserman. 1977. Erythroid colony formation by polycythemia vera bone marrow in vitro. J. Clin.
Invest. 59:841-848.
15. Casadevall, N., W. Vainchenker, C. Lacombe, G. Vinci, J. Chapman, J. Breton-Gorius, and B. Varet. 1982. Erythroid progenitors in polycythemia vera: demonstration of their hypersensitivity to erythropoietin using serum free cultures. Blood. 59:447-451.

16. Mitjavila, M. T., J. L. Villeval, P. Cramer, A. Henri, J. Gasson, G. Krystal, M. Tulliez, R. Berger, J. Breton-Gorius, and W. Vainchenker. 1987. Effects of granulocyte-macrophage colony-stimulating factor and erythropoietin on leukemic erythroid colony formation in human early erythroblastic leukemias. Blood. 70:965-973.

17. Anderson, W. F., B. Beckman, G. Beltran, J. W. Fisher, and W. J. Stuckey 1982. Erythropoietin-independent erythroid colony formation in patients with erythroleukemia (M6) and related disorders. Br. J. Haematol. 52:311-317.

18. Li, J.-P., A. D. D'Andrea, H. F. Lodish, and D. Baltimore. 1990. Activation of cell growth by binding of Friend spleen focus-forming virus gp 55 glycoprotein to the erythropoietin receptor. Nature (Lond.). 343:762-764.

19. Chung, S. W., L. Wolff, and S. K. Ruscetti. 1989. Transmembrane domain of the envelope gene of a polycythemia-inducing retrovirus determines erythropoietin-independent growth. Proc. Natl. Acad. Sci. USA. 86:7957-7960.

20. Yoshimura, A., A. D. D'Andrea, and H. F. Lodish. 1990. Friend spleen focus-forming virus glycoprotein gp55 interacts with the erythropoietin receptor in the endoplasmic reticulum and affects receptor metabolism. Proc. Natl. Acad. Sci. USA. 87:4139-4143.

21. Iscove, N. N., L. J. Guilbert, and C. Weyman. 1980. Complete replacement of serum in primary cultures of erythropoietin-dependent red cell precursors (CFU-E) by albumin, transferrin, iron, unsaturated fatty acid, lecithin and cholesterol. Exp. Cell Res. 126:121-126.

22. Chomczynski, P., and N. Sacchi. 1987. Single-step method of RNA isolation by acid guanidinium thiocyanate-phenol-chloroform extraction. Anal. Biochem. 162:156-159.

23. Feinberg, A. P., and B. Vogelstein. 1983. A technique for radiolabeling of DNA restriction endonuclease fragments to higt specific activity. Anal. Biochem. 132:6-13.

24. Maniatis, T., E. F. Fritsch, and J. Sambrook. 1982. Molecular Cloning: A Laboratory Manual. Cold Spring Harbor Laboratory, Cold Spring Harbor, NY. 25. Saiki, R. K., D. H. Gelfand, S. Stoffel, S. J. Sharf, R. Higuchi, G. T. Horn, K. B. Mullis, and H. A. Erlich. 1988. Primer directed enzymatic amplification of DNA with a thermostable DNA polymerase. Science (Wash. DC). 239:487-491. 26. Lin, F.-K., S. Suggs, C.-H. Lin, J. K. Browne, R. Smalling, J. C. Egrie, K. K. Chen, G. Fox, F. Martin, Z. Stabinsky, S.-M. Badrawi, P. H. Lai, and E. Goldwasser. 1985. Cloning and expression of the human erythropoietin gene. Proc. Natl. Acad. Sci. USA. 82:7580-7584.

27. Jacobs, K. J., C. Shoemaker, R. Rudersdorf, S. D. Neill, R. J. Kaufman, A. Mufson, J. Seehra, S. S. Jones, R. Hewick, E. F. Fritsch, M. Kawakita, T. Shimizu, and T. Miyake. 1985. Isolation and characterization of genomic and cDNA clones of human erythropoietin. Nature (Lond.). 313:806-810.

28. Wang, A. M., M. V. Doyle, and D. K. Mark. 1989. Quantitation of mRNA by the polymerase chain reaction. Proc. Natl. Acad. Sci. USA. 86:97179721.

29. Cox, K. H., D. V. DeLeon, L. M. Angerer, and R. C. Angerer. 1984. Detection of $m$ RNAs in sea urchin embryos by in situ hybridization using asymmetric RNA probes. Dev. Biol. 101:485-502.

30. Lawrence, J. B., and R. H. Singer. 1985. Quantitative analysis of in situ hybridization methods for the detection of actin gene expression. Nucleic Acids Res. 13:1777-1799.

31. Navarro, S., N. Debili, J. F. Bernaudin, W. Vainchenker, and J. Doly. 1989. Regulation of the expression of IL-6 in human monocytes. J. Immunol. 142:4339-4345

32. Mayeux, P., C. Billat, and R. Jacquot. 1987. The erythropoietin receptor of rat erythroid progenitor cells. Characterization and affinity cross linkage. $J$. Biol. Chem. 262:13985-13990.

33. Nakasawa, M., M. T. Mitjavila, N. Debili, N. Casadevall, P. Mayeux, P. Rouyer-Fessard, A. Dubart, P. H. Roméo, Y. Beuzard, K. Kishi, et al. 1989. KU 812: a pluripotent human cell line with spontaneous erythroid terminal maturation. Blood. 73:2003-2013.

34. Caracciolo, D., D. Venturelli, M. Valtieri, C. Peschle, A. M. Gewirtz, and B. Calabretta. 1990. Stage-related proliferative activity determines c-myb functional requirements during normal human hematopoiesis. J. Clin. Invest. 85:5561.

35. Egrie, J. C., P. M. Cotes, J. Lane, R. E. Gaines Das, and R. C. Tam. 1987 Development of radioimmunoassays for human erythropoietin using recombinant erythropoietin as tracer and immunogen. J. Immunol. Methods. 99:235241.

36. Lang, R. A., D. Metcalf, N. M. Gough, A. R. Dunn, and T. J. Gonda. 1985. Expression of a hematopoietic growth factor cDNA in a factor dependent cell line results in autonomous growth and tumorigenicity. Cell. 43:531-542.

37. Graf, T., and H. Beug. 1983. Role of the v-erbA and v-erbB oncogenes of avian erythroblastosis virus in erythroid cell transformation. Cell. 34:7-9.

38. Heard, J. M., M. F. Roussel, C. W. Rettenmier, and C. J. Sherr. 1987. Multilineage hematopoietic disorders induced by transplantation of bone marrow cells expressing the v-fms oncogene. Cell. 51:663-673. 
39. Tambourin, P., N. Casadevall, J. Choppin, C. Lacombe, J. M. Heard, S. Fichelson, F. Wendling, W. D. Hankins, and B. Varet. 1983. Production of erythropoietin like activity by a murine erythroleukemia cell line. Proc. Natl. Acad. Sci. USA. 80:6269-6273.

40. Choppin, J., C. Lacombe, N. Casadevall, O. Muller, P. Tambourin, and B. Varet. 1984. Characterization of erythropoietin produced by IW32 murine erythroleukemia cells. Blood. 64:341-347.

41. Krantz, S. B., and E. Golwasser. 1984. Specific binding of erythropoietin to spleen cells infected with the anemia strain of Friend virus. Proc. Natl. Acad. Sci. USA. 81:7574-7578.

42. Koury, S. T., M. C. Bondurant, and M. J. Koury. 1988. Localization of erythropoietin synthesizing cells in murine kidneys by in situ hybridization. Blood. 71:524-529.

43. Lacombe, C., J.-L. Da Silva, P. Bruneval, J.-G. Fournier, F. Wendling, N. Casadevall, J.-P. Camilleri, J. Barrety, B. Varet, and P. Tambourin. 1988. Peritubular cells are the site of erythropoietin synthesis in the murine hypoxic kidney. $J$. Clin. Invest. 81:620-623.

44. Maxwell, A. P., T. R. J. Lappin, C. F. Johnston, J. M. Bridges, and M. G. McGeown. 1990. Erythropoietin production in kidney tubular cells. Br. J. Haematol. 74:535-539.

45. Rich, I. N., W. Heit, and B. Kubanek. 1982. Extrarenal erythropoietin production by macrophages. Blood. 60:1007-1018.

46. Ymer, S., O. J. Tucker, C. J. Sanderson, H. D. Hapel, H. D. Campbell, and I. G. Young. 1985. Constitutive synthesis of interleukin 3 by leukemia cell line WEHI-3B is due to retroviral insertion near the gene. Nature (Lond.). 317:255258.

47. Andrejauskas, E., and C. Moroni. 1989. Reversible abrogation of IL-3 dependance by an inducible H-Ras oncogene. EMBO (Eur. Mol. Biol. Organ.) J. 8:2575-2581.

48. Young, D. C., and J. D. Griffin. 1986. Autocrine secretion of GM-CSF in acute myeloblastic leukemia. Blood. 68:1178-1181.

49. Young, D. C., K. Wagner, and J. D. Griffin. 1987. Constitutive expression of the granulocyte-macrophage colony-stimulating factor gene in acute myeloblastic leukemia. J. Clin. Invest. 79:100-106.

50. Bot, F. J., P. Schipper, L. Broeders, R. Dewels, K. Kaushansky, and B. Löwenberg. 1990. Interleukin-1 alpha also induces granulocyte-macrophage colony stimulating factor in immature normal bone marrow cells. Blood. 76:307311.

51. Laker, C, C. Stocking U. Bergholz, N. Hess, J. F. De Lamarter, and W. Ostertag. 1987. Autocrine stimulation after transfer of the granulocyte/macrophage colony-stimulating factor gene and autonomous growth are distinct but interdependent steps in the oncogenic pathway. Proc. Natl. Acad. Sci. USA. 84:8458-8462.

52. Dunbar, C. E., T. M. Browder, J. S. Abrams, and A. W. Nienhuis. 1989. $\mathrm{COOH}$-terminal-modified interleukin-3 is retained intracellularly and stimulates autocrine growth. Science (Wash. DC). 245:1493-1496.

53. Lang, R. A., D. Metcalf, R. A. Cuthberson, I. Lyons, E. Stanley, A. Kelso, G. Kannourakis, D. J. Williamson, G. K. Klinworth, T. J. Gonda, and A. R. Dunn. 1987. Transgenic mice expressing a hematopoietic growth factor gene (GM-CSF) develop accumulations of macrophages, blindness and a fatal syndrome of tissue damage. Cell. 51:675-685.

54. Chang J. M., D. Metcalf, R. A. Lang T. J. Gonda, and G. R. Johnson. 1989. Non-neoplastic hemopoietic myeloproliferative syndrome induced by dysregulated multi-CSF (IL-3) expression. Blood. 73:1487-1497.

55. Johnson, G. R., T. J. Gonda, D. Metcalf, I. K. Hariharan, and S. Cory. 1989. A lethal myeloproliferative syndrome in mice transplanted with bone marrow cells infected with a retrovirus expressing granulocyte-macrophage colony stimulating factor. EMBO (Eur. Mol. Biol. Organ.) J. 8:441-448.

56. Wong P. M. C., S. W. Chung C. E. Dunbar, D. M. Bodine, S. Ruscetti, and A. W. Nienhuis. 1989. Retrovirus-mediated transfer and expression of the interleukin-3 gene in mouse hematopoietic cells result in a myeloproliferative disorder. Mol. Cell. Biol. 9:798-808.

57. Semenza, G. L., M. D. Traystman, J. D. Gearhart, and S. E. Antonarakis. 1989. Polycythemia in transgenic mice expressing the human erythropoietin gene. Proc. Natl. Acad. Sci. USA. 86:2301-2305. 